\title{
The Role and Molecular Mechanism of P2Y12 Receptors in the Pathogenesis of Atherosclerotic Cardiovascular Diseases
}

\author{
Lu Wang ${ }^{1,+}$, Jinxuan Wang ${ }^{1,+}{ }^{+}$, Jianxiong $\mathrm{Xu}^{1}{ }^{1}$, Weixi Qin ${ }^{1}$, Yuming Wang ${ }^{1}$, Shisui Luo ${ }^{2, *}$ and Guixue Wang ${ }^{1, *}$ \\ 1 Key Laboratory for Biorheological Science and Technology of Ministry of Education, State and Local Joint \\ Engineering Laboratory for Vascular Implants, Bioengineering College of Chongqing University, \\ Chongqing 400030, China; wanglu@cqupt.edu.cn (L.W.); 20151902024t@cqu.edu.cn (J.W.); \\ 20161902002t@cqu.edu.cn (J.X.); 20201901030@cqu.edu.cn (W.Q.); yumingwang@mail.tmmu.com.cn (Y.W.) \\ 2 Taiji Group Co., Ltd., Chongqing 401147, China \\ * Correspondence: 1ss@taiji.com (S.L.); wanggx@cqu.edu.cn (G.W.) \\ + Co-first author: Equally contributed.
}

check for updates

Citation: Wang, L.; Wang, J.; Xu, J.; Qin, W.; Wang, Y.; Luo, S.; Wang, G. The Role and Molecular Mechanism of P2Y12 Receptors in the Pathogenesis of Atherosclerotic Cardiovascular Diseases. Appl. Sci. 2021, 11, 9078. https://doi.org/ 10.3390/app11199078

Academic Editor:

Manousos Makridakis

Received: 12 August 2021

Accepted: 26 September 2021

Published: 29 September 2021

Publisher's Note: MDPI stays neutral with regard to jurisdictional claims in published maps and institutional affiliations.

Copyright: (c) 2021 by the authors. Licensee MDPI, Basel, Switzerland. This article is an open access article distributed under the terms and conditions of the Creative Commons Attribution (CC BY) license (https:// creativecommons.org/licenses/by/ $4.0 /)$.

\begin{abstract}
The P2Y receptor family is a class of G protein-coupled receptors activated primarily by adenosine triphosphate (ATP), adenosine diphosphate (ADP), uridine triphosphate (UTP) and uridine diphosphate (UDP). The P2Y12 receptor is expressed on platelets which mediates platelet aggregation and morphological changes. At the same time, during the process of vascular remodeling and atherosclerosis, ADP can also promote the migration and proliferation of vascular smooth muscle and endothelial cells through P2Y12 receptor activating. Furthermore, P2Y12 is involved in many signal transductions processes, such as intimal hyperplasia, monocyte infiltration and so on, which play an important role in immune inflammation and brain injury. In order to solve the diseases induced by P2Y12 receptor, inhibitors such as ticagrelor, clopidogrel were widely used for cardiovascular diseases. However, there were some problems, such as limited antithrombotic effect, remain unsolved. This article summarizes the role and molecular mechanism of P2Y12 receptors in the pathogenesis of cardiovascular-related diseases, providing in-depth expounding on the molecular mechanism of P2Y12 receptor inhibitors and contributing to the treatment of diseases based on P2Y12 receptors.
\end{abstract}

Keywords: P2Y12 receptor; cardiovascular disease; fluid shear stress

\section{Introduction}

The P2Y receptor family is a class of G protein-coupled receptors (GPCRs) activated mainly by ATP, ADP, UTP and UDP. They are widely distributed in humans and are closely related to several physiological functions. In the human genome, the P2Y receptor includes eight members. After the identification of P2Y1 and P2Y2, P2Y4, P2Y6, P2Y11, P2Y12, P2Y13 and P2Y14 are successfully separated. P2Y receptors can be divided into Gq and Gi protein-coupled receptors based on the binding proteins of subunits [1-3].

The P2Y12 receptor is a rhodopsin-like G protein-coupled receptor consisting of 342 amino acid residues. The receptor gene is located in human chromosome 3q25.1 [4]. P2Y12 dominates the platelet aggregation mechanism regulated by soluble agonists and participates in the platelet aggregation mechanism driven by hemodynamics, and first discovered on platelets, is activated by ADP. Furthermore, P2Y12 receptor was also found on vascular smooth muscle, microglia, dendritic cells, macrophages and lymphocytes, which played an important role in guiding cells to a specific area [5,6]. In clinic, the P2Y12 receptor also plays an important role in various diseases such as thrombus myocardial atherosclerosis, brain injury repair process, and so on $[7,8]$. This article summarizes the role and mechanism of P2Y12 receptor-associated cardiovascular disease, explores the key role of P2Y12 receptor in the development of the disease further and provides new ideas for the combined clinical use of P2Y12 inhibitor drugs and drug conversion [9]. 


\section{P2Y12 Receptor and Fluid Shear Stress}

Blood vessels are constantly subjected to various types of blood flow due to pulsating blood flow and pressure, including fluid shear stress, cyclic stretching and hydrostatic pressure, which could regulate P2Y12 to activate syk kinase and PI3k kinase to induce platelet aggregation $[10,11]$. This phenomenon can activate various chemical and physical signals, modulating various physiological processes. In physiological blood shear rate $\left(1000-10,000 \mathrm{~s}^{-1}\right)$, small transient platelets aggregate through the development of membrane tethers [12], whereas at the pathological shear rate $\left(>410,000 \mathrm{~s}^{-1}\right)$, platelets can be activated independently by integrin $\alpha \mathrm{Ilb} \beta 3$ to form aggregation [13]. Meanwhile, disturbed blood flow also occurred platelet aggregation in vascular injury sites [14,15]. During platelet aggregation, the P2Y12 receptor can amplify and maintain the activation of ADP on platelets, release platelet particles, activate platelet mechanical membrane adhesion factors such as glycoprotein IIb/IIIa (GP IIb/IIIa) and ultimately maintain the growth and stability of the thrombus [16-18]. The P2Y12 receptor also plays an important role in stabilizing blood clots formed on atherosclerotic plaques [3,19]. However, P2Y12 is limited to high shear flow conditions and functions in the presence of coagulation [20].

ADP is involved in regulating vascular development, especially in changing hemodynamic environment, may play an important role in vascular reconstruction [6]. Some studies have found that ADP can affect the morphology, skeleton structure, migration, proliferation and apoptosis of endothelial cells, which affect the absorption and metabolism of lipoproteins and other macromolecular substances in the blood vessel wall [5]. ADP also regulate the synthesis, secretion and expression of vasoactive substances, to regulate the function of blood vessels reconstruction [21]. Activating the P2Y receptor of endothelial cells in vitro can change their form and permeability [22]. In the angiogenesis model, ADP significantly inhibits angiogenesis [23]. At the same time, endothelial cell migration experiments also found that ADP has a strong chemotactic effect on endothelial cells [24]. It may be that ADP activates the P2Y receptor to cause activation of the MAPK pathway, thereby promoting endothelial cell migration [25]. Platelet activation induced by ADP will also increase the expression level of VEGF in plasma and participate in the repair of vascular injury [26]; ADP inhibitors can reduce the release of VEGF and delay the healing of gastric ulcers [27]. Thus, the P2Y receptor plays a crucial role in regulating the homeostasis of endothelial cells.

\section{P2Y12 and Thrombosis}

Thrombus caused by the abnormal activation of platelets is the pathological basis for the formation of many diseases. Under various physiological and pathological conditions, platelets can be activated and undergo processes such as adhesion, deformation, aggregation, particle release and synthesis of thromboxane A2, which ultimately leads to physiological hemostasis or pathological thrombosis [28]. Platelet activation participates in the injury repair response during vascular injury, which is very important for the physiological hemostasis process. Furthermore, in the process of damage repair, platelets are activated in blood vessels and will indirectly adhere to subendothelial collagen through von Willebrand factor (vWF) [29,30]. Meanwhile, the platelet surface membrane glycoproteins GPVI and GPIa/IIa are also activated and directly adhere to collagen. However, under pathological conditions, when the blood flow shear rate is high, the GPIb/IX/V-vWFcollagen axis plays a key role in mediating the initial unstable platelet adhesion process, which is important for $\mathrm{Ib} / \mathrm{IX} / \mathrm{V}-\mathrm{vWF}$-collagen. Blocking of the axis is a key target for blocking platelet adhesion and subsequent reactions [31-33]. Among them, ARC-1779, as a nucleic acid aptamer of $\mathrm{vWF}$, can block $\mathrm{vWF}$ and GPIb/IX/V by binding to the A1 region of vWF [34]. At the same time, abnormal platelet activation also causes arterial thrombosis to cause blood vessel stenosis or occlusion, resulting in ischemia of the body tissue or interruption of blood supply, which ultimately leads to the pathological basis of arterial thrombotic diseases such as coronary heart disease, acute coronary syndrome, stroke, sticky platelet syndrome, etc. $[18,35,36]$. The following protein-coupled receptors 
are important receptors on the surface of platelets: thrombin receptors, PAR1, PAR3 and PAR4; ADP receptors, P2Y1 and P2Y12; prostaglandin receptors, such as thromboxane, prostacyclin, PDG2 and PGE2 receptors; and some lipid and chemokine receptors [37,38].

ADP is the earliest and most important substance in the body that induces platelet aggregation. ADP exists in high-density granules in platelet cells, and is released when platelets undergo an aggregation reaction. In sticky platelet syndrome, due to the increased aggregation of ADP and epinephrine, a variety of unexplained thromboembolic diseases result [39]. Human platelets have two ADP receptors: the Gq-coupled P2Y1 and Gi-coupled P2Y12 receptors. Among them, P2Y1 receptor is distributed on platelets and other tissue cells. P2Y12 receptors are mainly distributed on platelets and glial cells and have been most studied on platelets. ADP released from damaged blood vessels and red blood cells in the in vivo environment mediates platelet aggregation by acting on the two G-protein coupled receptor subtypes 2 and 3. Platelet surface ADP receptors mainly include P2Y1 and P2Y12. P2Y1 is a Gq protein coupled receptor, and P2Y12 is a Gi protein coupled receptor (Figure 1). When the ADP activates the P2Y1 receptor, it increases the intracellular free $\mathrm{Ca}^{2+}$ and changes the platelet morphology, causing reversible aggregation. After ADP activates the P2Y12 receptor, the initial platelet aggregation induced by the P2Y12 receptor can cause the release of dense particles in the platelets (including a large amount of ADP), inhibit adenylate cyclase and trigger irreversible platelet aggregation [40,41]. The P2Y1 receptor can only cause weak platelet activation, while P2Y12 can gradually amplify the signal. At the same time, the number of P2Y12 receptors on platelet membranes far exceeds that of P2Y1, so P2Y12 receptors have become one of the important targets of antiplatelet drugs [42]. P2Y12 receptor-mediated platelet activation is mainly achieved through the following mechanisms:

1. Inhibiting adenylate cyclase, reducing the concentration of cyclic adenosine monophosphate (cAMP), thereby increasing the free $\mathrm{Ca}^{2+}$ concentration, inactivating the cyclic adenosine monophosphate-dependent protein kinase and promoting platelet aggregation (first-phase gathering).

2. The first-phase aggregation reaction can activate PI3K kinase and promote the release of related substances (ADP, serotonin, etc.) in platelets, resulting in continuous and stable platelet aggregation (second-phase aggregation).

3. Activating phosphatidylinositol-3 kinase, serine-threonine protein kinase $\mathrm{B}$ and rapid guanosine triphosphate (GTP) binding protein, promote the exposure of the active site of platelet GPIIb/IIIa receptor binding to fibrinogen and promote platelet fibrin crosslinking and aggregation between platelets $[43,44]$.These interactions are facilitated by the release of the intracellular tether of GP IIb/IIIa, possibly via release from cytoskeletal actin components (the so-called inside-out signaling), which allows the extracellular domains of the GP IIb/IIIa receptor complex to expose multiple binding sites for fibrinogen and, also, for the von Willebrand factor [45]. Therefore, the P2Y12 receptor plays a vital role in platelet activation and aggregation. Furthermore, platelet aggregation may affect the infiltration of monocytes into the infarcted myocardium and influence the prognosis, which is contributed by P2Y12 [46]. The unique feature of P2Y12 may mediate platelet independent responses, especially in enhanced thrombin formation, such as local vascular injury and the rupture of atherosclerotic plaques [47]. Although this new biological signal is associated with long-term functional outcomes, the corresponding cellular substrates remain unclear.

Given that P2Y12 receptors regulate platelet activation and thrombosis, some antithrombotic drugs can covalently bind to P2Y12 receptors, including the highly active compounds clopidogrel and prasugrel. The nucleoside analogue ticagrelor, which is used to prevent stroke and myocardial infarction, acts directly on this receptor [48]. The analysis of the crystal structure of the complex of P2Y12 with the non-nucleotide reversible antagonist AZD1283 revealed the unique linear conformation of the spiral V, thereby differentiating P2Y12 from all other known class A GPCR structures (Table 1). In the case of binding to AZD1283, highly conserved disulfides in GPCRs are not observed between helix III 
and extracellular loop 2. The analysis of the extracellular interface revealed an adjacent ligand-binding region and suggested that both substances may be required for dinucleotide binding. This structure provides important ideas for developing improved P2Y12 ligands and allosteric modulators as drug candidates [49] (Table 1).

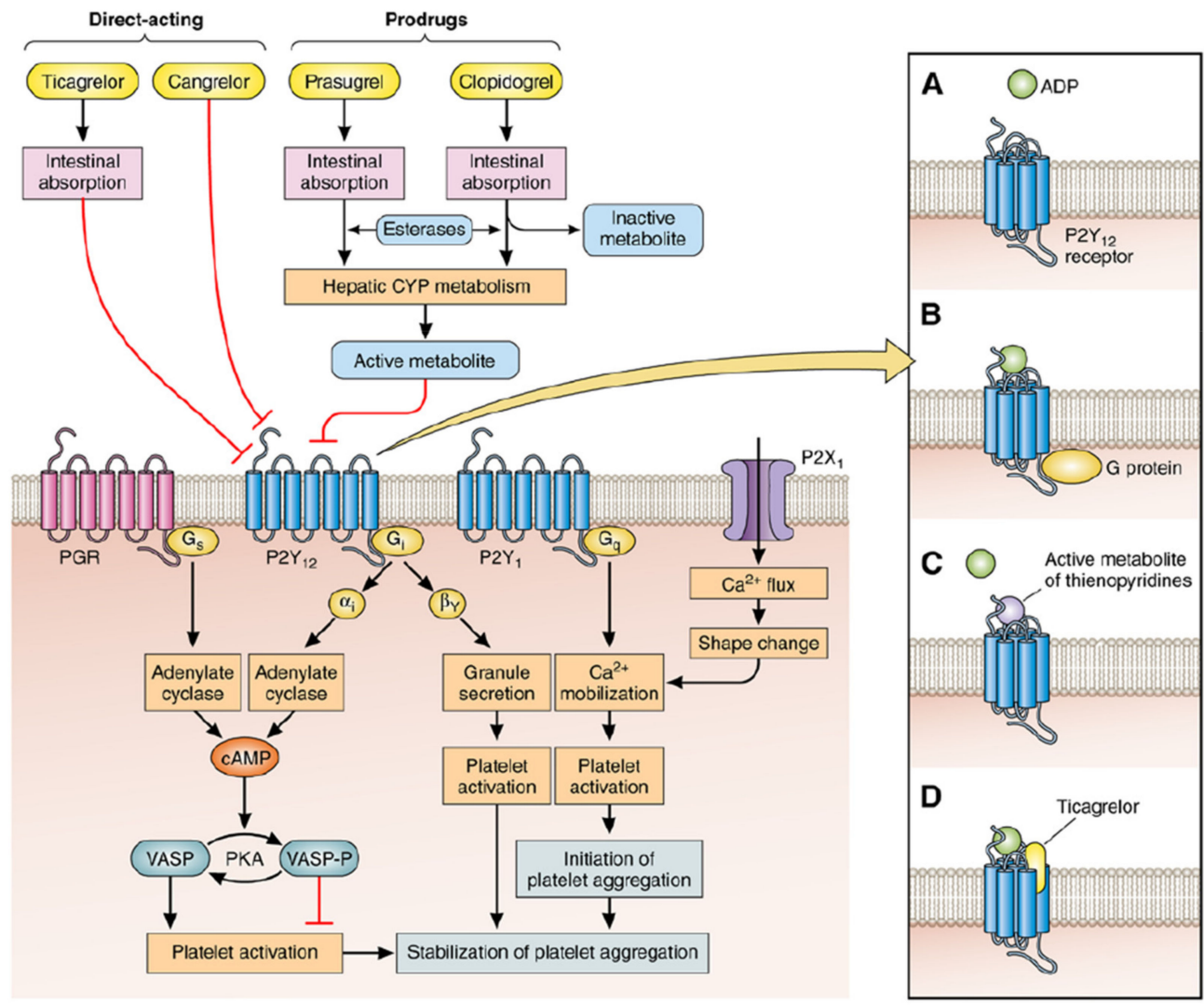

Figure 1. The activation of $\mathrm{P} 2 \mathrm{Y} 12$ receptor in platelet activation and other biological process.

Table 1. The treatment drugs of diseases based on P2Y12 receptors.

\section{P2Y12 Inhibitors}

Clopidogrel

Prasugrel

Ticagrelor
The Targets Functions of Drugs

References

Clopidogrel is a P2Y12 receptor inhibitor which selectively inhibits the binding of ADP to platelet receptors, the activation of ADP-mediated glycoprotein GPIIb/IIIa complex, and platelet aggregation. It is used to prevent and treat heart, brain and other arterial circulatory disorders caused by high platelet aggregation, such as recent strokes, myocardial infarctions and confirmed peripheral arterial diseases.

Prasugrel is a new orally effective thienopyridine drug. The P2Y12 adenosine diphosphate receptor on platelets can be irreversibly inhibited after the cytochrome P450 enzyme system is metabolized to the active metabolite.

Prasugrel has a higher conversion rate of prodrug to active metabolites and higher bioavailability, so it takes effect faster and can reduce the difference in efficacy between individuals, and reduces major ischemic cardiovascular events to a greater extent Incidence rate.

Ticagrelor is an oral P2Y12 receptor antagonist, which is a new type of cyclopentyl triazole pyrimidine oral antiplatelet drug. Ticagrelor promotes a greater inhibition of adenosine $5^{\prime}$-diphosphate (ADP)-induced $\mathrm{Ca}^{2+}$ release in shed platelets compared with other P2Y12R antagonists. Studies have also shown that ticagrelor is significantly better than clopidogrel. In clinical trial,

[50-52] 2 different dosages, 90 twice daily and $60 \mathrm{mg}$ once a day of ticagrelor both showed reduced risk of cardiovascular death. 
Table 1. Cont.

\begin{tabular}{cccc}
\hline P2Y12 Inhibitors & The Targets Functions of Drugs & References \\
\hline AZD1283 & $\begin{array}{c}\text { The P2Y12 receptor inhibitor AZD1283 induces an increasing in blood flow and } \\
\text { inhibits ADP-induced platelet aggregation, with antithrombotic ED50 values of } \\
3.0 \text { and } 10 \mu \mathrm{g} / \mathrm{kg} / \mathrm{min} \text {. }\end{array}$ \\
$\begin{array}{c}\text { 2-Methylthioadenosine diphosphate trisodium is a potent purinergic P2Y } \\
\text { 2-Methylthioadenosine } \\
\text { diphosphate trisodium }\end{array}$ & $\begin{array}{c}\text { receptor agonist, 2-methylthioadenosine diphosphate trisodium induces platelet } \\
\text { aggregation and shape change, and inhibits cyclic AMP accumulation in } \\
\text { platelets exposed to prostaglandin E1. }\end{array}$ \\
[61] & $\begin{array}{c}\text { An adenosine triphosphate analogue, a reversible and selective platelet P2Y12 } \\
\text { antagonist, has a rapid and effective antiplatelet effect. Cangrelor tetrasodium } \\
\text { directly blocks adenosine diphosphate (ADP)-induced platelet activation and } \\
\text { aggregation. Cangrelor tetrasodium is also a non-specific GPR17 antagonist. }\end{array}$ & [65-67] \\
\hline
\end{tabular}

\section{P2Y12 Receptor and Atherosclerosis}

Atherosclerosis is the most important atherosclerotic condition in clinical practice. It causes cerebrovascular disease and coronary heart disease among other diseases. It severely threatens the health and life of middle-aged and elderly people (10.1016/j.jacc.2018.08.1043) [68]. Atherosclerosis is characterized by the accumulation and bleeding of lipids and complex sugars, resulting in fibrous tissue hyperplasia and calcium deposition, and the gradual metamorphosis and calcification of the middle layer of arteries [69].

In atherosclerosis, acute vascular obstruction causes thrombosis, further producing atherosclerosis and vasoconstriction [70]. The occlusive effect of these aggregates combines with their inherent instability and tendency to embolic distal circulation. Thus, this aggregation mechanism may enhance cerebral blood vessel symptoms of acute coronary syndrome and intermittent thromboembolism [71]. In addition, this aggregation process can occur independent of soluble agonists, further illustrating the important role of platelet aggregation mechanism driven by hemodynamic changes [11]. This phenomenon may help explain the limited antithrombotic effect of aspirin, clopidogrel and thrombin inhibitors, especially in individuals with severe vascular diseases. These findings help reconcile some fundamental controversies in the field and provide a mechanical explanation for discoid platelet formation and aggregation. Acute plaque rupture leads to the rapid formation of non-occlusive thrombus. Under the action of P2Y12 blocker, the thrombus volume is small and unstable. In vitro, when mouse or human blood is perfused onto collagen or atherosclerotic plaque material, the occlusion or deficiency of P2Y12 can reduce thromboembolic events [72].

In a recent report, the P2Y12 receptor plays an important role in the progress of plaques, speculating that it may be through the promotion of platelets and leukocytes adhesion and aggregation affect the recruitment of leukocytes to the plaque area and mediate plate formation [73]. In subsequent experiments, some researchers proved by bone marrow transplantation that the P2Y12 receptor on the blood vessel wall is a key factor in promoting the development of early atherosclerosis [74]. The latest research also shows that P2Y12 receptors are also expressed in human carotid plaques and are mainly distributed on smooth muscle cells in plaques [6]. At the same time, atherosclerosis factor ox-ldl can induce smooth muscle cells to express the P2Y12 receptor and inhibit the cAMP/PKA signalling pathway by activating the transcription factor NF- $k B$, thereby inducing the dephosphorylation of the framework protein conflin and the depolymerization of fibrous actin, thereby promote skeleton protein renewal and enhance smooth muscle migration ability $[75,76]$. Platelet P2Y12 also regulates the release of platelet factor 4 by inhibiting the $\mathrm{CAMP}$ / protein kinase A pathway, affecting the recruitment and infiltration of monocytes [77]. F0F1 ATPase on the cell surface can catalyze the ADP produced by ATP hydrolysis in endothelial cells and stimulate the binding and internalization of apoA-I and HDL (Figure 1) [78,79]. The inhibition of P2Y12 by clopidogrel can reduce platelet-related inflammatory responses and the expression of p-selectin and CD40L after atherosclerotic 
thrombosis [80]. Ticagrelor and clopidogrel can effectively reduce platelet reactivity by inhibiting the P2Y12 receptor, but they cannot inhibit the formation of early atherosclerosis. The role of P2Y12 inhibitors is mainly reflected in the development of atherosclerotic diseases [74].

\section{Discussion and Prospect}

Since the discovery of the self-activation of GPCRs, our understanding of receptor activation and disease mechanisms has dramatically changed. In this review, we summarized the related signal transduction processes of P2Y12 receptors that participate in the physiological and pathological processes of diseases in various ways. These receptors play an important role in the formation of many human diseases, especially cardiovascular diseases. P2Y12 can directly participate in the formation of thrombus and also activate Syk kinase and PI3K kinase to induce thrombus formation in the biomechanical-mediated aggregation mechanism. Antiplatelet therapy that targets ADP receptor P2Y12 has become the main strategy to prevent acute coronary events and coronary stent thrombosis. At present, the main P2Y12 inhibitors used in clinic are clopidogrel, prasugrel and ticagrelor. However, their effects are closely related to the occurrence and development of the disease. For example, P2Y12 antagonists, such as clopidogrel, effectively prevent atherothrombotic thrombosis and are widely used. However, some studies discovered that clopidogrel has no effect on the treatment of atherosclerosis [81]. This contradictory result suggests the need for further research on P2Y12 receptor. This result prompted us to further study the therapeutic mechanism of P2Y12 receptor and explore the effect of this receptor on disease occurrence in different environments.

In addition, P2Y12 participates in the physiological and pathological processes of the cardiovascular system in different ways. First, P2Y12 receptor plays an important role in LPS-induced inflammation, which may be involved in the regulation of spleen and bone marrow cell content during LPS systemic inflammation. P2Y12 can promote the release of platelet and the aggregation of inflammatory $\alpha$-granules and platelets. The P2Y12 inhibitor clopidogrel can inhibit platelet-related inflammation and decrease the expressions of systemic inflammatory markers. In addition, P2Y12 receptors in brain tissue are closely related to glial cell chemotaxis, inflammatory factor release, and pain regulation. At the same time, miRNAs that regulate P2Y12 signalling are also considered to be new disease biomarkers and therapeutic targets, which have attracted attention. It regulates the expression of genes after transcription to exert biological functions, thereby participating in the regulation of various physiological functions of the body, and is closely related to the pathophysiological processes of various diseases. Recent studies have found that microRNA have high expression in platelets which participation in the regulation of platelet function and play an important role in the pathophysiological process of thrombotic cardio-cerebrovascular diseases. miR-223 can regulate the expression of P2Y12 in platelets and a variety of cells. miR-223 could influence the cutting process of mRNA and affect the expression of P2Y12. With the deepening of research on microRNA, the biological function of microRNA and its target genes will be discovered more and more. The importance of microRNA for cardiovascular diseases also needs to be further discovered.

Research on ion channels and $G$ protein-coupled receptors and signalling molecules has changed our understanding of P2Y12. This activation not only affects platelet aggregation, but also regulates changes in multiple signalling pathways within the cell, such as regulating smooth muscle cytoskeletal morphology and controlling vascular tone and remodeling. At the same time, through the local release of ADP, the vascular tension and tensile stress are affected [82,83]. Studies on P2Y12 receptors and signalling pathways have shown that P2Y12 receptors play an important role in diseases such as atherosclerosis, inflammatory diseases and neuropathy, and are potential drug targets. However, the interaction between the P2Y12 receptor and other signalling proteins and the interaction with other cell signalling pathways requires further study. 
The role of P2Y12 in the recruitment of inflammatory cells in the perturbed flow area is also worthy of further study.

Under normal physiological conditions, the blood flow in the blood vessels is mainly laminar, but in certain bifurcated stenoses, the blood flow will be separated due to interference and the flow process. The result of this change is the formation of some so-called vortex zones, which changes the laminar flow of blood into turbulent flow, which strengthens the impact on the blood vessel wall, and also causes damage to some parts of the intima of the blood vessel. It accelerates and promotes the accumulation of some harmful substances in the vicinity. Peripheral blood monocytes migrate into the inner membrane and can differentiate into macrophages. Macrophages can use the scavenger receptors on their surface to take up lipids to form a source of macrophages in atherosclerotic plaques. Foam cells have become an important cause of accelerated atherosclerosis [84,85].

In the initial stage of atherosclerosis, endothelial cells are first damaged to cause dysfunction, which in turn causes lipid deposition, macrophage recruitment, foam cell formation and T lymphocyte and platelet aggregation. The P2Y12 receptor is a member of the $\mathrm{P} 2$ receptor family. The P2 receptor consists of the ion channel receptor P2X family and the G protein-coupled receptor P2Y family. Platelets, endothelial cells and immune cells can release ATP or ADP, and ATP and ADP can bind to P2 receptors as ligands to activate P2 receptors. Additionally, the P2Y12 receptor is also mainly expressed in platelets and brain tissue glial cells. Platelet P2Y12 receptor plays an important role in maintaining platelet activation. The P2Y12 receptor in brain tissue is closely related to glial cell chemotaxis, inflammatory factor release and pain regulation. In recent years, the P2Y12 receptor on the blood vessel wall has gradually attracted people's attention. The P2Y12 receptor on normal vascular smooth muscle tissue can regulate the contractile function of blood vessels [76]. In addition, some studies have found that P2Y12 receptors are expressed in human carotid plaques and coronary atherosclerotic plaques, and compared with plaques in patients with stable and colic, P2Y12 receptors in plaques in patients with acute myocardial infarction have higher expression level [86]. The formation of atherosclerotic plaques includes a series of specific cellular and molecular reactions. Some studies have found that by comparing Low-Density Lipoprotein Receptor (LDLR), P2Y12 double knockout mice and LDLR single knockout mice, the P2Y12 receptor plays an important role in the progress of plaque [87], and its potential mechanism may be through the promotion of platelet adhesion and aggregation of leukocytes and the recruitment of leukocytes to the plaque area. Therefore, we speculate that P2Y12 as an immune cell activation receptor is closely related to immune cell recruitment behavior exposed to fluid shear stress. Further clarification of the role of P2Y12 in the recruitment of inflammatory cells in the perturbed flow area will provide a basis for our in-depth understanding of the relationship between P2Y12 as an immune cell activation receptor and immune cell recruitment exposed to fluid shear stress.

Author Contributions: Conceptualization, G.W. and S.L.; investigation, L.W. and J.W.; writingoriginal draft preparation, L.W., J.W., G.W. and J.X.; writing-review and editing, W.Q., S.L., J.X., Y.W. and G.W.; supervision, G.W. and S.L.; project administration, G.W. and S.L.; funding acquisition, G.W. and Y.W. All authors have read and agreed to the published version of the manuscript.

Funding: This research was funded by the National Natural Science Foundation of China, grant number 31971242, the Chongqing Science and Technology Bureau, grant number cstc2019jcyj-zdxmX0028, and the State Key Project Specialized for Infectious Diseases, grant number 2017ZX10201201-001005, 2017ZX10201201-002-005, Chongqing Municipal Education Commission, China, grant number KYYJ202001.

Institutional Review Board Statement: Not applicable.

Informed Consent Statement: Not applicable.

Conflicts of Interest: The authors declare that there is no conflict of interest regarding the publication of this paper. 


\section{References}

1. Wang, Y.X.; Shi, Y.H.; Gong, L.H.; Li, Y.; Heng, W.J.; You, J.F.; Zhong, H.H.; Fang, W.G. P2Y purinergic receptor activated $\mathrm{PI}-3 \mathrm{~K} /$ Akt signaling pathway in regulation of growth and invasion of prostatic cancer. Zhonghua Bing Li Xue Za Zhi 2007, 36, 681-686. [PubMed]

2. Von Kügelgen, I. Molecular pharmacology of P2Y receptor subtypes. Biochem. Pharmacol. 2021, 187, 114361. [CrossRef] [PubMed]

3. Chiarito, M.; Sanz-Sánchez, J.; Cannata, F.; Cao, D.; Stefanini, G.G. Monotherapy with a P2Y12 inhibitor or aspirin for secondary prevention in patients with established atherosclerosis: A systematic review and meta-analysis. Lancet 2020, 395, 1487-1495. [CrossRef]

4. Pokorski, M. Rehabilitation Science in Context Volume 1096 | | Psychological Determinants of Attitude Toward Euthanasia: A Comparative Study of Female Nurses and Female Nonmedical Professionals. Adv. Exp. Med. Biol. 2018, 93-103. [CrossRef]

5. Burnstock, G. Purinergic Signaling in the Cardiovascular System. Circ. Res. 2017, 120, 207-228. [CrossRef] [PubMed]

6. Li, F.; Xu, D.; Hou, K.; Gou, X.; Li, Y. The role of P2Y12 receptor inhibition in ischemic stroke on microglia, platelets and vascular smooth muscle cells. J. Thromb. Thrombolysis 2020, 50, 874-885. [CrossRef]

7. Pereira, N.L.; Farkouh, M.E.; So, D.; Lennon, R.; Geller, N.; Mathew, V.; Bell, M.; Bae, J.H.; Jeong, M.; Chavez, H. Effect of Genotype-Guided Oral P2Y12 Inhibitor Selection vs Conventional Clopidogrel Therapy on Ischemic Outcomes After Percutaneous Coronary Intervention: The TAILOR-PCI Randomized Clinical Trial. JAMA 2020, 324, 761-771. [CrossRef]

8. Kim, H.J.; Oh, J.S.; Park, S.Q.; Yoon, S.M.; Ahn, H.S.; Kim, B.T. The Efficacy of P2Y12 Reactive Unit to Predict the Periprocedural Thromboembolic and Hemorrhagic Complications According to Clopidogrel Responsiveness and Safety of Modification of Dual Antiplatelet Therapy: A Meta-Analysis. J. Korean Neurosurg. Soc. 2019, 63, 539-549. [CrossRef]

9. Baldetti, L.; Melillo, F.; Moroni, F.; Gallone, G.; Pagnesi, M.; Venuti, A.; Beneduce, A.; Calvo, F.; Gramegna, M.; Godino, C.; et al. Meta-Analysis Comparing P2Y12 Inhibitors in Acute Coronary Syndrome. Am. J. Cardiol. 2020, 125, 1815-1822. [CrossRef]

10. Roka-Moiia, Y.; Walk, R.; Palomares, D.E.; Ammann, K.R.; Slepian, M.J. Platelet activation via shear stress exposure induces a differing pattern of biomarkers of activation versus biochemical agonists. Thromb. Haemost. 2020, 120, 776-792. [CrossRef]

11. Nesbitt, W.S.; Westein, E.; Tovar-Lopez, F.J.; Tolouei, E.; Mitchell, A.; Fu, J.; Carberry, J.; Fouras, A.; Jackson, S.P. A shear gradient-dependent platelet aggregation mechanism drives thrombus formation. Nat. Med. 2009, 15, 665-673. [CrossRef]

12. Maxwell, M.J.; Westein, E.; Nesbitt, W.S.; Giuliano, S.; Jackson, S.P.J.B. Identification of a 2-stage platelet aggregation process mediating shear-dependent thrombus formation. Blood 2007, 109, 566-576. [CrossRef] [PubMed]

13. Ruggeri, Z.M.; Orje, J.N.; Habermann, R.; Federici, A.B.; Reininger, A.J. Activation-independent platelet adhesion and aggregation under elevated shear stress. Blood 2006, 108, 1903-1910. [CrossRef] [PubMed]

14. Bhatt, D.L.; Topol, E.J. Scientific and therapeutic advances in antiplatelet therapy. Nat. Rev. Drug Discov. 2003, 2, 15-28. [CrossRef]

15. Antithrombotic Trialists' Collaboration. Collaborative meta-analysis of randomised trials of antiplatelet therapy for prevention of death, myocardial infarction, and stroke in high risk patients. BMJ 2002, 324, 71-86. [CrossRef]

16. Muniz-Lozano, A.; Rollini, F.; Franchi, F.; Angiolillo, D.J. Update on platelet glycoprotein IIb/IIIa inhibitors: Recommendations for clinical practice. Ther. Adv. Cardiovasc. Dis. 2013, 7, 197-213. [CrossRef] [PubMed]

17. Storey, R.F.; Newby, L.J.; Heptinstall, S. Effects of P2Y(1) and P2Y(12) receptor antagonists on platelet aggregation induced by different agonists in human whole blood. Platelets 2001, 12, 443-447. [CrossRef]

18. Franchi, F.; Angiolillo, D.J. Novel antiplatelet agents in acute coronary syndrome. Nat. Rev. Cardiol. 2015, 12, 30-47. [CrossRef]

19. Pi, S.; Mao, L.; Chen, J.; Shi, H.; Liu, Y.; Guo, X.; Li, Y.; Zhou, L.; He, H.; Yu, C.; et al. The p2ry12 receptor promotes vsmc-derived foam cell formation by inhibiting autophagy in advanced atherosclerosis. Autophagy 2021, 17, 980-1000. [CrossRef]

20. Griffin, G.K.; Newton, G.; Tarrio, M.L.; Bu, D.X.; Maganto-Garcia, E.; Azcutia, V.; Alcaide, P.; Grabie, N.; Luscinskas, F.W.; Croce, K.J.; et al. IL-17 and TNF-alpha sustain neutrophil recruitment during inflammation through synergistic effects on endothelial activation. J. Immunol. 2012, 188, 6287-6299. [CrossRef]

21. Giachini, F.R.; Leite, R.; Osmond, D.A.; Lima, V.V.; Inscho, E.W.; Webb, R.C.; Tostes, R.C. Anti-platelet therapy with clopidogrel prevents endothelial dysfunction and vascular remodeling in aortas from hypertensive rats. PLoS ONE 2014, 9, e91890. [CrossRef]

22. Tanaka, N.; Kawasaki, K.; Nejime, N.; Kubota, Y.; Nakamura, K.; Kunitomo, M.; Takahashi, K.; Hashimoto, M.; Shinozuka, K. P2Y receptor-mediated $\mathrm{Ca}^{2+}$ signaling increases human vascular endothelial cell permeability. J. Pharmacol. Sci. 2004, 95, 174-180. [CrossRef]

23. Barnhill, R.L.; Ryan, T.J. Biochemical modulation of angiogenesis in the chorioallantoic membrane of the chick embryo. J. Investig. Dermatol. 1983, 81, 485-488. [CrossRef]

24. Teuscher, E.; Weidlich, V. Adenosine nucleotides, adenosine and adenine as angiogenesis factors. Biomed. Biochim. Acta 1985, 44, 493-495.

25. Shen, J.; DiCorleto, P.E. ADP stimulates human endothelial cell migration via P2Y1 nucleotide receptor-mediated mitogenactivated protein kinase pathways. Circ. Res. 2008, 102, 448-456. [CrossRef] [PubMed]

26. Maloney, J.P.; Silliman, C.C.; Ambruso, D.R.; Wang, J.; Tuder, R.M.; Voelkel, N.F. In vitro release of vascular endothelial growth factor during platelet aggregation. Am. J. Physiol. 1998, 275, H1054-H1061. [CrossRef] [PubMed]

27. Ma, L.; Elliott, S.N.; Cirino, G.; Buret, A.; Ignarro, L.J.; Wallace, J.L. Platelets modulate gastric ulcer healing: Role of endostatin and vascular endothelial growth factor release. Proc. Natl. Acad. Sci. USA 2001, 98, 6470-6475. [CrossRef] [PubMed]

28. Qiao, J.; Arthur, J.F.; Gardiner, E.E.; Andrews, R.K.; Zeng, L.; Xu, K. Regulation of platelet activation and thrombus formation by reactive oxygen species. Redox. Biol. 2018, 14, 126-130. [CrossRef] 
29. Chen, J.; Chung, D.W. Inflammation, von Willebrand factor, and ADAMTS13. Blood 2018, 132, 141-147. [CrossRef]

30. Ishihara, J.; Ishihara, A.; Starke, R.D.; Peghaire, C.R.; Smith, K.E.; McKinnon, T.A.; Tabata, Y.; Sasaki, K.; White, M.J.V.; Fukunaga, K.; et al. The heparin binding domain of von Willebrand factor binds to growth factors and promotes angiogenesis in wound healing. Blood 2019, 133, 2559-2569. [CrossRef]

31. Malehmir, M.; Pfister, D.; Gallage, S.; Szydlowska, M.; Inverso, D.; Kotsiliti, E.; Leone, V.; Peiseler, M.; Surewaard, B.G.J.; Rath, D.; et al. Platelet GPIb $\alpha$ is a mediator and potential interventional target for NASH and subsequent liver cancer. Nat. Med. 2019, 25, 641-655. [CrossRef] [PubMed]

32. Braun, L.J.; Stegmeyer, R.I.; Schäfer, K.; Volkery, S.; Currie, S.M.; Kempe, B.; Nottebaum, A.F.; Vestweber, D. Platelets docking to VWF prevent leaks during leukocyte extravasation by stimulating Tie-2. Blood 2020, 136, 627-639. [CrossRef] [PubMed]

33. Hanke, J.; Ranke, C.; Perego, E.; Köster, S. Human blood platelets contract in perpendicular direction to shear flow. Soft Matter 2019, 15, 2009-2019. [CrossRef] [PubMed]

34. Veyradier, A. A new drug for an old concept: Aptamer to von Willebrand factor for prevention of arterial and microvascular thrombosis. Haematologica 2020, 105, 2512-2515. [CrossRef]

35. Wu, L.; Zhao, F.; Dai, M.; Li, H.; Chen, C.; Nie, J.; Wang, P.; Wang, D.W. P2Y12 Receptor Promotes Pressure Overload-Induced Cardiac Remodeling via Platelet-Driven Inflammation in Mice. Hypertension 2017, 70, 759-769. [CrossRef]

36. Sokol, J.; Skerenova, M.; Ivankova, J.; Simurda, T.; Stasko, J. Association of Genetic Variability in Selected Genes in Patients With Deep Vein Thrombosis and Platelet Hyperaggregability. Clin. Appl. Thromb. Hemost. 2018, 24, 1027-1032. [CrossRef]

37. Ni, H.; Denis, C.V.; Subbarao, S.; Degen, J.L.; Sato, T.N.; Hynes, R.O.; Wagner, D.D. Persistence of platelet thrombus formation in arterioles of mice lacking both von Willebrand factor and fibrinogen. J. Clin. Investig. 2000, 106, 385-392. [CrossRef]

38. Becker, R.C.; Gurbel, P.A. Platelet P2Y12 receptor antagonist pharmacokinetics and pharmacodynamics: A foundation for distinguishing mechanisms of bleeding and anticipated risk for platelet-directed therapies. Thromb. Haemost. 2010, 103, 535-544. [CrossRef]

39. Yagmur, E.; Bast, E.; Mühlfeld, A.S.; Koch, A.; Weiskirchen, R.; Tacke, F.; Neulen, J. High Prevalence of Sticky Platelet Syndrome in Patients with Infertility and Pregnancy Loss. J. Clin. Med. 2019, 8, 1328. [CrossRef]

40. Angiolillo, D.J.; Rollini, F.; Storey, R.F.; Bhatt, D.L.; James, S.; Schneider, D.J.; Sibbing, D.; So, D.Y.F.; Trenk, D.; Alexopoulos, D.; et al. International Expert Consensus on Switching Platelet P2Y12 Receptor-Inhibiting Therapies. Circulation 2017, 136, 1955-1975. [CrossRef]

41. Rollini, F.; Franchi, F.; Angiolillo, D.J. Switching P2Y12-receptor inhibitors in patients with coronary artery disease. Nat. Rev. Cardiol. 2016, 13, 11-27. [CrossRef] [PubMed]

42. Grosdidier, C.; Blanz, K.D.; Deharo, P.; Bernot, D.; Poggi, M.; Bastelica, D.; Wolf, D.; Duerschmied, D.; Grino, M.; Cuisset, T.; et al. Platelet CD40 ligand and bleeding during P2Y12 inhibitor treatment in acute coronary syndrome. Res. Pract. Thromb. Haemost. 2019, 3, 684-694. [CrossRef]

43. Kossmann, S.; Lagrange, J.; Jackel, S.; Jurk, K.; Ehlken, M.; Schonfelder, T.; Weihert, Y.; Knorr, M.; Brandt, M.; Xia, N.; et al. Platelet-localized FXI promotes a vascular coagulation-inflammatory circuit in arterial hypertension. Sci. Transl. Med. 2017, 9, eaah4923. [CrossRef] [PubMed]

44. Amelirad, A.; Shamsasenjan, K.; Akbarzadehlaleh, P.; Pashoutan Sarvar, D. Signaling Pathways of Receptors Involved in Platelet Activation and Shedding of These Receptors in Stored Platelets. Adv. Pharm. Bull. 2019, 9, 38-47. [CrossRef] [PubMed]

45. Simurda, T.; Brunclikova, M.; Asselta, R.; Caccia, S.; Zolkova, J.; Kolkova, Z.; Loderer, D.; Skornova, I.; Hudecek, J.; Lasabova, Z.; et al. Genetic Variants in the FGB and FGG Genes Mapping in the Beta and Gamma Nodules of the Fibrinogen Molecule in Congenital Quantitative Fibrinogen Disorders Associated with a Thrombotic Phenotype. Int. J. Mol. Sci. 2020, 21, 4616. [CrossRef]

46. Wrigley, B.J.; Shantsila, E.; Tapp, L.D.; Lip, G.Y. Increased formation of monocyte-platelet aggregates in ischemic heart failure. Circ. Heart Fail. 2013, 6, 127-135. [CrossRef]

47. Rauch, B.H.; Rosenkranz, A.C.; Ermler, S.; Bohm, A.; Driessen, J.; Fischer, J.W.; Sugidachi, A.; Jakubowski, J.A.; Schror, K.J.A.T.V.B. Regulation of Functionally Active P2Y12 ADP Receptors by Thrombin in Human Smooth Muscle Cells and the Presence of P2Y12 in Carotid Artery Lesions. Arterioscler. Thromb. Vasc. Biol. 2010, 30, 2434-2442. [CrossRef]

48. Jung, S.M.; Moroi, M. Platelet collagen receptor integrin alpha2beta1 activation involves differential participation of ADP-receptor subtypes P2Y1 and P2Y12 but not intracellular calcium change. Eur. J. Biochem. 2001, 268, 3513-3522. [CrossRef]

49. Zhang, K.; Zhang, J.; Gao, Z.G.; Zhang, D.; Zhu, L.; Han, G.W.; Moss, S.M.; Paoletta, S.; Kiselev, E.; Lu, W.; et al. Structure of the human P2Y12 receptor in complex with an antithrombotic drug. Nature 2014, 509, 115-118. [CrossRef]

50. Isfort, K.; Ebert, F.; Bornhorst, J.; Sargin, S.; Kardakaris, R.; Pasparakis, M.; Bahler, M.; Schwerdtle, T.; Schwab, A.; Hanley, P.J Real-time imaging reveals that P2Y2 and P2Y12 receptor agonists are not chemoattractants and macrophage chemotaxis to complement C5a is phosphatidylinositol 3-kinase (PI3K)- and p38 mitogen-activated protein kinase (MAPK)-independent. J. Biol. Chem. 2011, 286, 44776-44787. [CrossRef]

51. Shan, J.; Zhang, B.; Zhu, Y.; Jiao, B.; Zheng, W.; Qi, X.; Gong, Y.; Yuan, F.; Lv, F.; Sun, H. Overcoming clopidogrel resistance: Discovery of vicagrel as a highly potent and orally bioavailable antiplatelet agent. J. Med. Chem. 2012, 55, 3342-3352. [CrossRef]

52. Pereira, N.L.; Rihal, C.S.; So, D.Y.F.; Rosenberg, Y.; Lennon, R.J.; Mathew, V.; Goodman, S.G.; Weinshilboum, R.M.; Wang, L.; Baudhuin, L.M.; et al. Clopidogrel Pharmacogenetics. Circ. Cardiovasc. Interv. 2019, 12, e007811. [CrossRef] 
53. Nijenhuis, V.J.; Brouwer, J.; Delewi, R.; Hermanides, R.S.; Holvoet, W.; Dubois, C.L.F.; Frambach, P.; De Bruyne, B.; van Houwelingen, G.K.; Van Der Heyden, J.A.S.; et al. Anticoagulation with or without Clopidogrel after Transcatheter Aortic-Valve Implantation. N. Engl. J. Med. 2020, 382, 1696-1707. [CrossRef]

54. Johnston, S.C.; Amarenco, P.; Denison, H.; Evans, S.R.; Himmelmann, A.; James, S.; Knutsson, M.; Ladenvall, P.; Molina, C.A.; Wang, Y.; et al. Ticagrelor and Aspirin or Aspirin Alone in Acute Ischemic Stroke or TIA. N. Engl. J. Med. 2020, 383, $207-217$. [CrossRef]

55. Mehran, R.; Baber, U.; Sharma, S.K.; Cohen, D.J.; Angiolillo, D.J.; Briguori, C.; Cha, J.Y.; Collier, T.; Dangas, G.; Dudek, D.; et al. Ticagrelor with or without Aspirin in High-Risk Patients after PCI. N. Engl. J. Med. 2019, 381, 2032-2042. [CrossRef] [PubMed]

56. Tomaniak, M.; Chichareon, P.; Onuma, Y.; Deliargyris, E.N.; Takahashi, K.; Kogame, N.; Modolo, R.; Chang, C.C.; RademakerHavinga, T.; Storey, R.F.; et al. Benefit and Risks of Aspirin in Addition to Ticagrelor in Acute Coronary Syndromes: A Post Hoc Analysis of the Randomized GLOBAL LEADERS Trial. JAMA Cardiol. 2019, 4, 1092-1101. [CrossRef] [PubMed]

57. Schupke, S.; Neumann, F.J.; Menichelli, M.; Mayer, K.; Bernlochner, I.; Wohrle, J.; Richardt, G.; Liebetrau, C.; Witzenbichler, B.; Antoniucci, D.; et al. Ticagrelor or Prasugrel in Patients with Acute Coronary Syndromes. N. Engl. J. Med. 2019, 381, 1524-1534 [CrossRef] [PubMed]

58. Gimbel, M.; Qaderdan, K.; Willemsen, L.; Hermanides, R.; Bergmeijer, T.; de Vrey, E.; Heestermans, T.; Tjon Joe Gin, M.; Waalewijn, R.; Hofma, S.; et al. Clopidogrel versus ticagrelor or prasugrel in patients aged 70 years or older with non-ST-elevation acute coronary syndrome (POPular AGE): The randomised, open-label, non-inferiority trial. Lancet 2020, 395, 1374-1381. [CrossRef]

59. Cesaro, A.; Taglialatela, V.; Gragnano, F.; Moscarella, E.; Fimiani, F.; Conte, M.; Barletta, V.; Monda, E.; Limongelli, G.; Severino, S.; et al. Low-Dose Ticagrelor in Patients With High Ischemic Risk and Previous Myocardial Infarction: A Multicenter Prospective Real-World Observational Study. J. Cardiovasc. Pharmacol. 2020, 76, 173-180. [CrossRef]

60. Bonaca, M.P.; Bhatt, D.L.; Cohen, M.; Steg, P.G.; Storey, R.F.; Jensen, E.C.; Magnani, G.; Bansilal, S.; Fish, M.P.; Im, K.; et al. Long-term use of ticagrelor in patients with prior myocardial infarction. N. Engl. J. Med. 2015, 372, 1791-1800. [CrossRef]

61. Bangalore, S. Prasugrel in the Elderly. Circulation 2018, 137, 2446-2449. [CrossRef]

62. Kong, D.; Xue, T.; Guo, B.; Cheng, J.; Liu, S.; Wei, J.; Lu, Z.; Liu, H.; Gong, G.; Lan, T.; et al. Optimization of P2Y12 Antagonist Ethyl 6-(4-((Benzylsulfonyl)carbamoyl)piperidin-1-yl)-5-cyano-2-methylnicotinate (AZD1283) Led to the Discovery of an Oral Antiplatelet Agent with Improved Druglike Properties. J. Med. Chem. 2019, 62, 3088-3106. [CrossRef]

63. Macfarlane, D.E.; Srivastava, P.C.; Mills, D.C. 2-Methylthioadenosine[beta-32P]diphosphate. An agonist and radioligand for the receptor that inhibits the accumulation of cyclic AMP in intact blood platelets. J. Clin. Investig. 1983, 71, 420-428. [CrossRef]

64. Kimura, M.; Nishi, K.; Higashikawa, A.; Ohyama, S.; Sakurai, K.; Tazaki, M.; Shibukawa, Y. High pH-Sensitive Store-Operated $\mathrm{Ca}\left({ }^{2+}\right)$ Entry Mediated by $\mathrm{Ca}^{2+}$ Release-Activated $\mathrm{Ca}^{2+}$ Channels in Rat Odontoblasts. Front. Physiol. 2018, 9, 443. [CrossRef] [PubMed]

65. Guarracino, J.F.; Cinalli, A.R.; Fernandez, V.; Roquel, L.I.; Losavio, A.S. P2Y13 receptors mediate presynaptic inhibition of acetylcholine release induced by adenine nucleotides at the mouse neuromuscular junction. Neuroscience 2016, 326, 31-44. [CrossRef]

66. Bhattad, V.B.; Gaddam, S.; Lassiter, M.A.; Jagadish, P.S.; Ardeshna, D.; Cave, B.; Khouzam, R.N. Intravenous cangrelor as a peri-procedural bridge with applied uses in ischemic events. Ann. Transl. Med. 2019, 7, 408. [CrossRef] [PubMed]

67. Zhan, T.; Wei, T.; Dong, L.; Wang, Q.; Wu, Z.; Yan, Q.; Zhang, W.; Lu, Y.; Wu, M. Cangrelor alleviates bleomycin-induced pulmonary fibrosis by inhibiting platelet activation in mice. Mol. Immunol. 2020, 120, 83-92. [CrossRef]

68. Beko, K.; Kovanyi, B.; Goloncser, F.; Horvath, G.; Denes, A.; Kornyei, Z.; Botz, B.; Helyes, Z.; Muller, C.E.; Sperlagh, B. Contribution of platelet P2Y12 receptors to chronic Complete Freund's adjuvant-induced inflammatory pain. J. Thromb. Haemost. 2017, 15, 1223-1235. [CrossRef] [PubMed]

69. Libby, P.; Loscalzo, J.; Ridker, P.; Farkouh, M.E.; Hsue, P.Y.; Fuster, V.; Hasan, A.A.; Amar, S. Inflammation, Immunity, and Infection in Atherothrombosis: JACC Review Topic of the Week. J. Am. Coll. Cardiol. 2018, 72, 2071-2081. [CrossRef] [PubMed]

70. Noels, H.; Weber, C. Fractalkine as an important target of aspirin in the prevention of atherogenesis: Editorial to: "Aspirin inhibits fractalkine expression in atherosclerotic plaques and reduces atherosclerosis in ApoE gene knockout mice" by $\mathrm{H}$. Liu et al. Cardiovasc. Drugs Ther. 2010, 24, 1-3. [CrossRef]

71. Sim, D.S.; Jeong, M.H.; Kim, H.S.; Gwon, H.C.; Seung, K.B.; Rha, S.W.; Chae, S.C.; Kim, C.J.; Cha, K.S.; Park, J.S.; et al. Association of potent P2Y12 blockers with ischemic and bleeding outcomes in non-ST-segment elevation myocardial infarction. J. Cardiol. 2019, 73, 142-150. [CrossRef] [PubMed]

72. Barrett, T.J.; Schlegel, M.; Zhou, F.; Gorenchtein, M.; Berger, J.S. Platelet regulation of myeloid suppressor of cytokine signaling 3 accelerates atherosclerosis. Sci. Transl. Med. 2019, 11, eaax0481. [CrossRef] [PubMed]

73. Nergiz-Unal, R.; Cosemans, J.M.; Feijge, M.A.; van der Meijden, P.E.; Storey, R.F.; van Giezen, J.J.; oude Egbrink, M.G.; Heemskerk, J.W.; Kuijpers, M.J. Stabilizing role of platelet P2Y(12) receptors in shear-dependent thrombus formation on ruptured plaques. PLoS ONE 2010, 5, e10130. [CrossRef] [PubMed]

74. Held, P.; Himmelmann, A.; Ditmarsch, M. Ticagrelor for the treatment of atherosclerotic disease: Insights from the PARTHENON clinical development program. Future Cardiol. 2016, 12, 405-418. [CrossRef] [PubMed]

75. West, L.E.; Steiner, T.; Judge, H.M.; Francis, S.E.; Storey, R.F. Vessel wall, not platelet, P2Y12 potentiates early atherogenesis. Cardiovasc. Res. 2014, 102, 429-435. [CrossRef] [PubMed] 
76. Wihlborg, A.K.; Wang, L.; Braun, O.O.; Eyjolfsson, A.; Gustafsson, R.; Gudbjartsson, T.; Erlinge, D. ADP receptor P2Y12 is expressed in vascular smooth muscle cells and stimulates contraction in human blood vessels. Arterioscler. Thromb. Vasc. Biol. 2004, 24, 1810-1815. [CrossRef] [PubMed]

77. Niu, X.; Pi, S.L.; Baral, S.; Xia, Y.P.; He, Q.W.; Li, Y.N.; Jin, H.J.; Li, M.; Wang, M.D.; Mao, L.; et al. P2Y12 Promotes Migration of Vascular Smooth Muscle Cells Through Cofilin Dephosphorylation During Atherogenesis. Arterioscler. Thromb. Vasc. Biol. 2017, 37, 515-524. [CrossRef]

78. Li, D.; Wang, Y.; Zhang, L.; Luo, X.; Li, J.; Chen, X.; Niu, H.; Wang, K.; Sun, Y.; Wang, X.; et al. Roles of purinergic receptor P2Y, G protein-coupled 12 in the development of atherosclerosis in apolipoprotein E-deficient mice. Arterioscler. Thromb. Vasc. Biol. 2012, 32, e81-e89. [CrossRef]

79. Cavelier, C.; Ohnsorg, P.M.; Rohrer, L.; von Eckardstein, A. The beta-chain of cell surface F(0)F(1) ATPase modulates apoA-I and HDL transcytosis through aortic endothelial cells. Arterioscler. Thromb. Vasc. Biol. 2012, 32, 131-139. [CrossRef]

80. Burger, P.C.; Wagner, D.D. Platelet P-selectin facilitates atherosclerotic lesion development. Blood 2003, 101, 2661-2666. [CrossRef]

81. Kang, H.J.; Clare, R.M.; Gao, R.; Held, C.; Himmelmann, A.; James, S.K.; Lim, S.T.; Santoso, A.; Yu, C.M.; Wallentin, L.; et al. Ticagrelor versus clopidogrel in Asian patients with acute coronary syndrome: A retrospective analysis from the Platelet Inhibition and Patient Outcomes (PLATO) Trial. Am. Heart J. 2015, 169, 899-905. [CrossRef] [PubMed]

82. Schulz, C.; Konrad, I.; Sauer, S.; Orschiedt, L.; Koellnberger, M.; Lorenz, R.; Walter, U.; Massberg, S. Effect of chronic treatment with acetylsalicylic acid and clopidogrel on atheroprogression and atherothrombosis in ApoE-deficient mice in vivo. Thromb. Haemost. 2008, 99, 190-195. [CrossRef] [PubMed]

83. Jager, B.; Stojkovic, S.; Haller, P.M.; Piackova, E.; Kahl, B.S.; Andric, T.; Vargas, K.G.; Wojta, J.; Huber, K. Course of platelet miRNAs after cessation of P2Y12 antagonists. Eur. J. Clin. Investig. 2019, 49, e13149. [CrossRef] [PubMed]

84. Zhang, W.M.; Liu, Y.; Li, T.T.; Piao, C.M.; Liu, O.; Liu, J.L.; Qi, Y.F.; Jia, L.X.; Du, J. Sustained activation of ADP/P2ry12 signaling induces SMC senescence contributing to thoracic aortic aneurysm/dissection. J. Mol. Cell. Cardiol. 2016, 99, 76-86. [CrossRef]

85. Cicha, I.; Yilmaz, A.; Suzuki, Y.; Maeda, N.; Daniel, W.G.; Goppelt-Struebe, M.; Garlichs, C.D. Connective tissue growth factor is released from platelets under high shear stress and is differentially expressed in endothelium along atherosclerotic plaques. Clin. Hemorheol. Microcirc. 2006, 35, 203-206.

86. Tabas, I.; Garcia-Cardena, G.; Owens, G.K. Recent insights into the cellular biology of atherosclerosis. J. Cell Biol. 2015, 209, 13-22. [CrossRef] [PubMed]

87. Gachet, C. P2Y(12) receptors in platelets and other hematopoietic and non-hematopoietic cells. Purinergic Signal 2012, 8, 609-619. [CrossRef] 